\title{
Qualitative and Quantitative Phytochemical Analysis of Moringa oleifera (Lam) Pods
}

\author{
Elzein M. Fahal, A.M. Babitha Rani, M.D. Aklakur, T.I. Chanu and Neelam Saharan*
}

ICAR-Central Institute of Fisheries Education, Mumbai, India

*Corresponding author

A B S T R A C T

\begin{tabular}{|c|c|}
\hline $\begin{array}{l}\text { Ke e y w o r d s } \\
\text { Phytochemicals, Moringa } \\
\text { oleifera, Qualitative, } \\
\text { quantitative, Extracts, } \\
\text { pods }\end{array}$ & $\begin{array}{l}\text { Moringa oleifera (Lam.) has remarkable medicinal properties and } \\
\text { nutritional value possessed by various parts of the tree Viz. leaves, seeds, } \\
\text { pods, roots and bark. The therapeutic effects of M. oleifera are due to the } \\
\text { combined actions or effects of various bioactive components or }\end{array}$ \\
\hline Artic & \\
\hline $\begin{array}{l}\text { Accepted: } \\
07 \text { April } 2018 \\
\text { Available Online: } \\
10 \text { May } 2018\end{array}$ & $\begin{array}{l}\text { these five important phyto-constituents in aqueous, ethanol, methanol and } \\
\text { chloroform extracts. Quantitative analysis was also carried out for the same } \\
\text { metabolites in Moringa pods' crude extract. }\end{array}$ \\
\hline
\end{tabular}

\section{Introduction}

Plants are unique source of food, medicinal artifacts, energy and shelter for both human and animal., many useful harvests obtained from plants directly or indirectly validate their importance to the human and other living organisms (Kawo, 2007). Moringa oleifera (Lam.) has many common names such as ben oil, drumstick, horseradish, and miracle tree. M. oleifera is a widely distributed species of the family Moringaceae. It is a small graceful, deciduous plant with thin foliage and can grow up to $8 \mathrm{~m}$ height (Keay, 1989). Moringa is native to Western and sub Himalayan regions, India, Pakistan, Asia and Africa and it is distributed throughout the world in arid and semi-arid climate (Makkar and Becker, 1997).
Moringa trees are having a remarkable range of medicinal properties as high as nutritional values. Most parts of the plant., leaves, seeds, fruit or pods, roots, stem, and bark are used as medicines or foods in various countries with especial references to the traditional communities. The leaves are rich source of both macro- and micronutrients, such as protein and many vitamins (Siddhuraju and Becker, 2003). Fresh leaf juice inhibits the growth of human pathogens (Das et al., 1957). The seeds also show antimicrobial activity (Oliveira et al., 1999). Fruits or pods have wide spectrum of antimicrobial and antifungal activities against common pathogens (Sayeed et al., 2012). The roots have been reported to have antispasmodic and antimicrobial activity and used for diarrhea treatment (Caceres et al., 
1992). Moringa contains specific plant pigments., alpha-carotene and beta-carotene, lutein and phytochemical constituents such as alkaloids, flavonoids, saponins, sterols, phenols and tannins. The therapeutic effects of $M$. oleifera could be due to the combined actions of various bioactive components found in the plant, including trace metal ions, vitamins, alkaloids, polyphenols and other elements (Coppin, 2008) and they collectively act on broad physiological processes including metabolism and immunity (Amaglo et al., 2010).

\section{Materials and Methods}

\section{Study area}

The research work was carried out at Division of Aquaculture, ICAR- Central Institute of Fisheries Education, Mumbai, Maharashtra, India. Moringa pods were collected from different trees around the CIFE campus in Versova area suburb of western Mumbai city.

\section{Plant materials}

Fresh dry samples from Moringa pods were submitted to Blatter Herbarium of ST. Xavier's College in Mumbai, India. The samples were identified and authenticated as Moringa oleifera (lam). The samples matched with the herbarium specimen number NI. 4891 of N. A. Irani. For the research work, fresh and dry pods were collected and seed were removed from dry pods. The pods were blended as fine powder using, normal electrical grinder and kept in air tight container for further analysis.

\section{Plant extraction}

Aqueous extract was prepared using method described by Awodele et al., (2012). $100 \mathrm{~g}$ of sample powder was macerated in 2 liters of distilled water (MILLPORE, Q-gard1) for 24 hours. The solution was decanted and filtered using Whatman filter paper No.1 (QUALIGEN- Germany). The filtrate was dried in oven (Hexatec, Model HIPL03A) at $40^{\circ} \mathrm{C}$ for 4 days. The dry extract again was reconstituted in distilled water and used for the qualitative analysis. Chloroform extract was prepared using method described by Sathishkumar and Baskar, (2014).

$100 \mathrm{~g}$ of sample powder was added to $400 \mathrm{ml}$ chloroform and was shacken in water bath for ten hours. The solution then filtered using Whatman filter paper No. 1. The filtrate was dried using Rotary evaporator (IKA, model RV10B) to get the filtrate which again was dissolved in same amount of the solvent and used for further analysis. Ethanol extract was prepared using method described by Olatunde and Dikwa, (2014). $80 \mathrm{~g}$ of the sample powder was added to $400 \mathrm{ml}$ ethanol (98\%) for 72 hours.

The solution was filtered using Whatman filter paper No. 1. The solvent was evaporated using rotary evaporator. The filterate was again dissolved in same amount of the solvent and was used for further analysis. Methanol extract was prepared using method described by Pavithra, et al., (2009). $50 \mathrm{~g}$ of the sample powder was added into a round beaker containing $500 \mathrm{ml}$ of Methanol and kept for 24 hours and the solution then filtered using Whatman filter paper No. 1. The filtrate was evaporated at room temperature to get the dry extract which was dissolved in same amount of methanol and stored for further analysis.

\section{Qualitative screening of bioactive components}

Each extract was tested for presence of alkaloids, flavonoids, saponines, sterols and tannins using different methods. The tests were performed in triplicates to ensure the accurate results. 


\section{Detection of alkaloids}

The occurrence of alkaloids was tested using method reported by Sabri et al., (2012). $10 \mathrm{ml}$ of the extract were evaporated to dryness. Two $\mathrm{ml}$ of $2 \% \mathrm{HCL}$ acid were added to the dry residue.

Few drops of Wagner's reagent were added to the solution. The presence of alkaloids was confirmed when reddish brown precipitate occurred.

\section{Detection of flavonoids}

The test was based on method described by Pamar et al., (2012). Few drops of $\mathrm{NaOH}$ were added to two $\mathrm{ml}$ of the extract and intense yellow color appeared. Few drops of dilute HCL were added and the solution turned to colorless as indicator of presence of flavonoids.

\section{Detection of saponins}

Precipitation and foam test method was used as described by Devmurari, (2010). Few drops of $(1 \%)$ lead acetate solution were added to one $\mathrm{ml}$ of the extracts. Intense white precipitate appeared due to presence of Saponins.

Foam test also confirmed presence of saponins in the extract, in which $20 \mathrm{ml}$ of distilled water were added to one $\mathrm{ml}$ of the extract in graduated cylinder. The solution was shacken for 5 to15 minutes and formation of stable foam indicated the presence of saponins.

\section{Detection of sterols}

The test was performed based on method described by Solihah et al., (2012). Two ml concentrated sulphuric acid were added to two $\mathrm{ml}$ of the extract. Formation of red precipitate indicated presence of sterols.

\section{Detection of tannins}

The test method was described by Ugochuhwu et al., (2013). One $\mathrm{ml}$ of $3 \%$ of Ferric chloride was added to one $\mathrm{ml}$ of the extract. Brownish green color development indicated presence of tannins.

\section{Quantitative analysis of the bioactive constitutes}

Different methods were used to determine the amount of the required constitutes in the pods based on gravimetric tests. Three replicates were used for each test to ensure the accuracy.

\section{Estimation of alkaloids}

Alkaloids were quantified by the method described by Agoreyo et al., (2012). Five grams sample was weighed into beaker and $200 \mathrm{ml}$ of $10 \%$ acetic acid in ethanol were added. The mixture was covered and allowed to stand for four hours. After that the mixture was filtered and the filtrate was concentrated on water bath (i-therm, model AI7482) at $100^{\circ} \mathrm{C}$, to one-quarter of the original volume.

Concentrated ammonium hydroxide was added to the extract in the form of drops until precipitation completed. After settlement, the extract was filtered and the precipitate washed with dilute ammonium hydroxide and then dried and weighed (Citizen sensitive balance, CY510 C).

\section{Estimation of flavonoids}

The method was described by Bharathidasan et al., (2013). $100 \mathrm{ml}$ of $80 \%$ aqueous methanol was used to extract ten grams of the sample. The mixture was filtered by using (QUALIGEN- Germany) Whatman filter paper No. $42(125 \mathrm{~mm})$. The filtrate was evaporated until dried, and then weighed until constant weight was achieved. 


\section{Estimation of saponins}

The method was described by Gupta (2013). 20 grams of plant sample was put into a conical flask and $100 \mathrm{ml}$ of $20 \%$ ethanol was added. The solution was heated over water bath at $100^{\circ} \mathrm{C}$ for 4 hours with continuous stirring at $55^{\circ} \mathrm{C}$. The solution was then filtered and the residue re-extracted with another 200 $\mathrm{ml}$ of $20 \%$ ethanol. The combined extracts were reduced to $40 \mathrm{ml}$ over a water bath.

The concentrate was transferred into a $250 \mathrm{ml}$ separating funnel and $20 \mathrm{ml}$ of diethyl ether was added to the extract and was vigorously shaken. The aqueous layer was recovered while the ether layer was discarded and the purification process was repeated. $60 \mathrm{ml}$ of $\mathrm{n}$ butanol was added, the combined extract was washed twice with $10 \mathrm{ml}$ of $5 \% \mathrm{NaCl}$. The remaining solution was heated in a water bath and after evaporation., the sample was dried in the oven at $105^{\circ} \mathrm{C}$ to a constant weight.

\section{Estimation of sterols}

Method described by Araujo et al., (2013), was used with some modification to get the gravimetric weight. The extract was cooled to room temperature $25^{\circ} \mathrm{C}$, filtered on cotton, and the residue (cotton and plant materials) reextracted twice, using $30 \mathrm{ml}$ of chloroform for $15 \mathrm{~min}$. The two filtrates were collected and were dried under reduced pressure at $40^{\circ} \mathrm{C}$, rotary evaporator. The residue was then placed to an oven at $80{ }^{\circ} \mathrm{C}$ until reached constant weigh.

\section{Estimation of tannins}

As method was described by Vetter and Barbosa, (1995), $100 \mathrm{ml}$ of distilled water was added to two grams of the sample. The solution was kept in water bath at $90^{\circ} \mathrm{C}$ for one hour. The mixture was filtered by using Whatman's paper No. 1 and the residue was re-extracted again. The two filtrates were collected together and allowed to cooldown. Distilled water was added to the filtrates up to $500 \mathrm{ml}$. One hundred $\mathrm{ml}$ of the solution transferred to a beaker, and then $10 \mathrm{ml}$ of $40 \%$ formaldehyde and $5 \mathrm{ml}$ of concentrated sulpheric acid were added respectively. The whole mixture was refluxed for 30 minutes and was left to cool down. The mixture was filtered and the precipitate dried and weighed.

\section{Results and Discussion}

\section{Qualitative analysis of phytochemical constitutes for Moringa pods}

Basically phytochemical screening or qualitative analysis is used to reveal the chemical constituents or the secondary metabolites of the plant extract or tissue in different plant parts. In the present study, preliminary phytochemical screening for pods' extract of $M$. oleifera revealed the presence of alkaloids, flavonoids, saponins, sterols and tannin (Table 1). Alkaloids were present in the aqueous, ethanol, methanol and chloroform extracts. Flavonoids were present in aqueous, ethanol, methanol extracts and were absent in the chloroform extract. Saponins were present in chloroform and ethanol extracts and were absent in aqueous and methanol extracts. Sterols were revealed in aqueous, ethanol, methanol and chloroform extracts. The phytochemical screening of Moringa oleifera (Patel et al., 2014) exhibited presence of alkaloids, flavonoids, saponins, sterols and tannins in both aqueous and ethanolic extracts of leaves. Presence of alkaloids, flavonoids, saponins, sterols and tannins in aqueous, ethanol, ether and chloroform extracts in leaves of Guava Psidium guajava L. was reported by Arya et al., (2012). Gupta et al., (2013) reported that in pods of Acacia concina, alkaloids were presented in aqueous and methanol extracts but absent in chloroform extract (Fig. 1-5). 
Fig.1 Moringa oleifera tree with pods

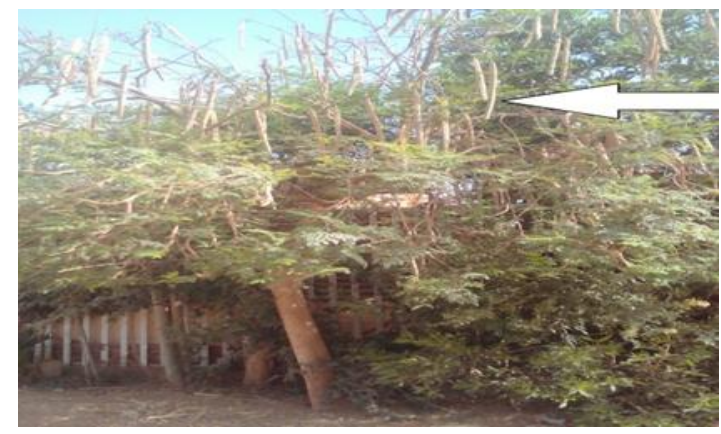

Fig.1 Alkaloids crude extract

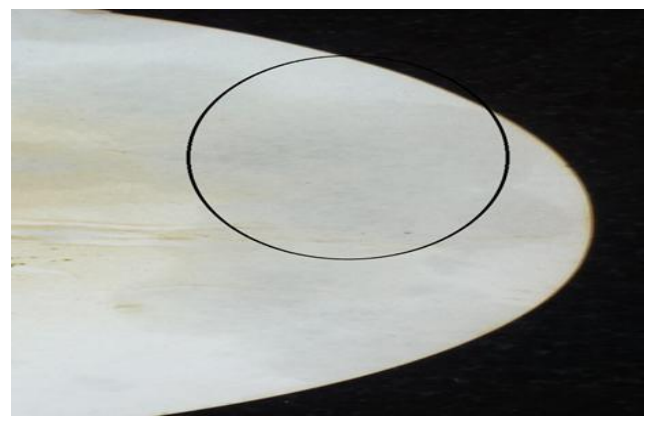

Fig.3 Flavonoids crude extract

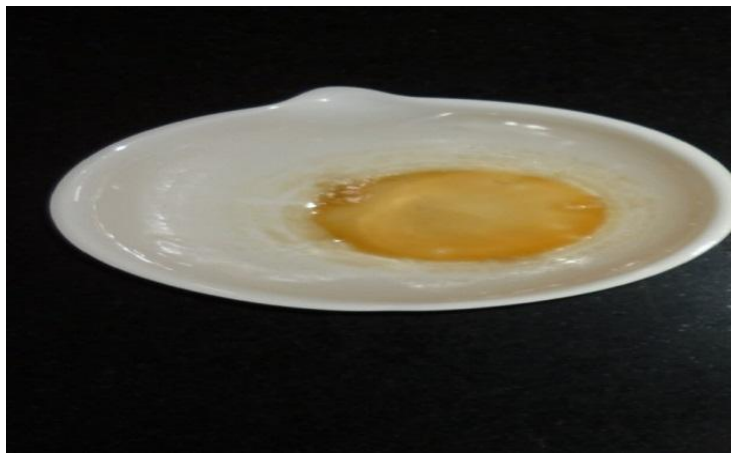

Fig.4 Saponins crude extract

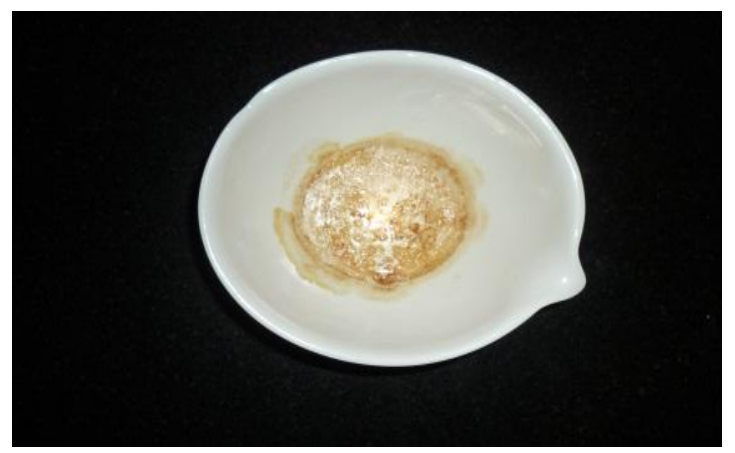


Fig.5 Tannins crude extract

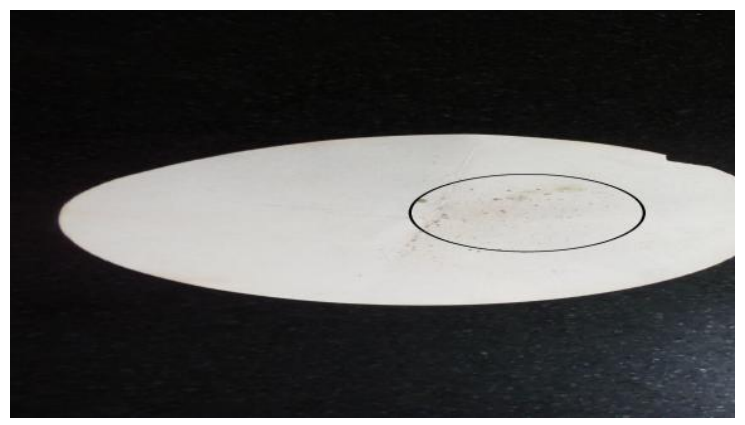

Table.1 Phytochemical screening of Moringa pod extracts

\begin{tabular}{|c|c|c|c|c|}
\hline \multicolumn{5}{|c|}{ Presence (+)/Absence (-) of secondary metabolites } \\
\hline Plant part & \multicolumn{5}{|c|}{ Pods } \\
& \multicolumn{5}{|c|}{ Solvent } \\
\hline Constituent & Aqueous & Ethanolic & Methanolic & Chloroform \\
\hline Alkaloids & + & + & + & + \\
\hline Flavonoids & + & + & + & - \\
\hline Saponines & - & + & - & + \\
\hline Sterols & + & + & + & + \\
\hline Tannins & + & - & + & - \\
\hline
\end{tabular}

Table.2 Quantitative analysis of secondary metabolites in crude extracts of Moringa pods (Mean \pm SE)

\begin{tabular}{|l|l|l|}
\hline S. No & Phytoconstituents & Quantity (\%) \\
\hline 1 & Alkaloids & $3.1 \pm 0.004$ \\
\hline 2 & Flavonoids & $5.2 \pm 0.003$ \\
\hline 3 & Saponins & $6.5 \pm 0.1$ \\
\hline 4 & Sterol & $4.7 \pm 0.002$ \\
\hline 5 & Tannins & $22.9 \pm 0.01$ \\
\hline
\end{tabular}

Flavonoids appeared in aqueous and methanolic extracts but absent in chloroform extract. Saponins, sterols and tannins, were absent in aqueous, methanol and chloroform extract. In the same study, screening of pods of Emblica officinalis revealed the presence of alkaloids in aqueous and methanolic extracts and absence in chloroform extract. Flavonoids appeared in methanol extract and were absent in aqueous and chloroform extract. Saponins and tannins were absent in aqueous, methanol and chloroform extracts. Sterols were presented in aqueous and methanol and were absent in chloroform extracts.

\section{Quantitative analysis of phytochemical}

\section{Constitutes for pods}

Quantitative analysis of secondary metabolites benefits to disclose the chemical 
constituents of the plant extract and to know which phytochemical conquered over the other. It can also be used to search for bioactive components for developed products that may contain medicinal values and can assist in synthesis of useful drugs (Harbone, 1998). The quantitative analysis result of secondary metabolites in Moringa pods shown in (Table 2). The amount of alkaloids in crude extract of pods was $(3.1 \%)$, amount of flavonoids was (5.2\%), amount of saponins was $(6.5 \%)$, amount of sterols was $(4.7 \%)$ and amount of tannins was $(22.9 \%)$. In Acacia coccina pods extract, the amount of alkaloids was (10.2\%), amount of flavonoids was $(7.2 \%)$, amount of saponins was $(0.51 \%)$ and amount of tannins was $(2.3 \%)$, while in Acacia catechu, amount of alkaloids was (11.3\%), amount of flavonoids was $(0.72 \%)$, amount of saponins was $(0.53 \%)$ and amount of tannins was $(2.1 \%)$. In pod extract of Emblica officinalis, quantity of alkaloids was (11.2\%), quantity of flavonoids was $(0.04 \%)$, quantity of saponins was $(0.55 \%)$, and quantity of tannins was (1.10\%), (Gupta et al., 2013). Fruit extract of Tribulus terrestris the quantity of alkaloids was $(0.75 \%)$, quantity of flavonoids was $(1.10 \%)$, amount of saponins was $(0.85 \%)$, and amount of tannins was (1.25\%), (Kumar ashwani et al., 2013). In some plant parts the amount of these phytoconstituents was comparatively higher as reported in a study for flower crude extract of Bauhinia tomentosa L. which showed that amount of alkaloids was (5.6\%), amount of flavonoids was (15.8\%) and amount of saponins was (2.1\%), (Sathya et al., 2013). General plant secondary metabolites or phytoconstituents are considered as good and unique source for food supplements and pharmaceuticals., their various roles were reported in many studies. The importance of alkaloids, sterols, saponins and tannins comes from their uses as antimicrobial for treating many pathogens (Kubmarawa, 2007) and (Mensah, 2008). Phyto-sterols and flavonoids have a role as immunomodulatory, anticancer, antioxidants, and anti-inflammatory agents (Laparra and Sanz, 2010). Alkaloids have anti-microbial and anti-fungal activities or properties, flavonoids have role in preventing liver peroxidation and anti-cancer properties, and sterols have anti-metastatic activity (Saxena et al., 2013). Alkaloids are also effective in reducing headaches resulting from hypertension (Ayitey and Addae, 1977).

\section{Declaration of interest}

Authors report no conflict of interest regarding present work.

\section{Acknowledgements}

Corresponding author and co- authors are grateful to Dr. Gopal Krishna the director/Vice-Chancellor of CIFE - Mumbai for providing ultimate fund for the research work.

\section{References}

Agoreyo, B.O, Obansa, A.S. and E.O. Obanor. 2012. Comparative nutritional and phytochemical analyses of two varieties of Solanum melongena. Sci. world J., 7(1): 5-8.

Amaglo, N.K., R. N. Bennett, R. B. Lo Curto, E.A.S. Rosa, V. Lo Turco, A. Giuffrid, A. Lo Curto, F. Creaand Timpo, G. M. 2010. Profilling selected phytochemicals and nutrients in different tissues of the multipurpose tree Moringa oleifera L., grown in Ghana. Food Chem., 122: 10471054

Araujo, L. B. D. C., S.L. Silvab, M.A. Maglvoc, M.R. Ferreiraa, E.L. Araujo, K.P. Randau and Soares, L. 2013. A. Total phytosterol content in drug materials and extracts from roots of Acanthospermum hispidum by UV-VIS spectrophotometry. Brazil $J$ of Pharmac., 23., 736-742. 
Arya, V., N.M. Thakur and Kashyap, C. 2012.Preliminary Phytochemical Analysis of the Extracts of Psidium Leaves. $J$ Pharmacogn Phytochem 1: 1-5

Ashwani K. and Ashish B. 2013.Comparative qualitative quantitative chemo-typic characterization among North Indian Tribulus terrestris. International Research Journal of Pharmacy. 3(6), 212-218Pp.

Awodele O, I. A. Oreagba, S. Odoma, J. A. da Silva.Osunkalu, V. O. 2012. Toxicological evaluation of the aqueous leaf extract of Moringa oleifera Lam. (Moringaceae). J Ethnopharmacol., 139 (2): 330-336.

Ayitey-Smith, E and Addae-Mensah, I. 1977. Phytochemical, nutritional and medical properties of some leafy vegetables consumed by Edo people of Nigeria. $W$. Afr. J. Pharmacol. Drug Res., 4: 7- 8

Bharathidasan, R., V.Sathya, V S.S. Tamil, N.R. Sophia, R. lakkiya and Prabakaran, M. 2013. Quantitative, qualitative phytochemical analysis and in vitro antibacterial activity of Bauhinia tomentosa L. J. Nat. Prod. Plant Resour., $3(2): 31-36$

Caceres, A., A. Saravia, S. Rizzo, L.Zabala, E. De Leon and Nave, F. 1992 Pharmacologic properties of Moringa oleifera. 2: screening for antispasmodic, anti-inflammatory and diuretic activity. Journal of Ethnopharmacology, 36(3), pp.233-237.

Coppin, J., 2008. A Study of the nutritional and medicinal values of Moringa oleifera Leaves from sub-Saharan Africa: Ghana, Rwanda, Senegal and Zambia. M. Sc. Thesis, the State University of New Jersey, New Jersey, USA.

Das, B.R., P.A. Kurup and Rao, P.L. 1957. Antibiotic principle from Moringa pterygosperma. VII. Antibacterial activity and chemical structure of compounds related to pterygospermin. The Indian Journal of Medical Research. 45(2) pp.191-196.
Devmurari, V. P. 2010. Phytochemical screening study and antibacterial evaluation of Symplocos racemosa Roxb. Archives of Applied Science Research, 2(1) 354-359.

Gupta, M., S. Thakur, A. Sharma and Gupta, S. 2013. Qualitative and Quantitative Analysis of Phytochemicals and Pharmacological Value of Some Dye Yielding Medicinal Plants. Orien. J. Chem., Vol. 29, No. (2): Pp. 475-48.

Harbone, J. B. (1998). Methods of extraction and isolation. In: Phytochemical methods: A guide to modern technique of plant analysis. 4th ed. London: Chapman and Hall.

Kawo, A.H. 2007. Water purification potentials and in-vivo toxicity evaluation of the aqueous and petroleum-ether extracts of Calotropis procera (Ait.F.) and Moringa oleifera Lam seed powder. $\mathrm{PhD}$ thesis, Microbiology Unit, Department of Biological Sciences, Bayero University, Kano, Nigeria. 184pp.

Keay, R.W. 1989.Trees of Nigeria. Revised edition. Calarendon Press, Oxford, USA. Pp1-450

Kubmarawa, D., Ajoku, G.A., Enworem, N.M. and Okorie, D. A. 2007. Roles of agricultural biotechnology in ensuring adequate food security in developing societies. Afr. J. Biotechnol., 6: 16901696.

Laparra, J. M. and Sanz, Y. 2010 Interactions of gut microbiota with functional components and nutraceuticals. Farmacol. Res. 61, 219-225.

Makkar, H. P. S., and Becker, k. 1997.Nutrients and antiquality factors in different morphological parts of the Moringa oleifera tree.J. Ag. Sci.: 128, pp. 311-322.

Mensah, J. K., Okoli,, R. I., Ohaju-Obodo, J.O. and Eifediyi, K. 2008. Aqueous extract of Telfairia occidentalis leaves reduces blood sugar and increases haematological and reproductive indices in male rats. Afr. J. Biotechnol., 7: 2304-2309.

Olatunde, A., and Dikwa, M.A. 2014. Qualitative and Quantitative Analysis of 
Phytochemicals of Loranthus bengwensis Leaf. Intern.l $J$ of Pharmace.Sci.., 05(01)., 0010.

Oliveira, J.T.A., S.B.Silveira, I.M. Vasconcelos, B.S. Cavada and Moreira, R. A. 1999. Compositional and nutritional attributes of seeds from the multiple purpose tree Moringa oleifera (Lam.) Journal of the Science of Food and Agriculture. 79(6), pp.815-820.

Parmar, P., S. Bhatt, S. Dhyani and Jain, A. 2012. Phytochemical studies of the secondary metabolites of Ziziphusm auritiana. International Jou of current Pharmace. Res., 4 (3): 153-155.

Patel, P., N. Patel, D. Patel, S. Desai and Meshram, D. 2014. Phytochemical analysis and antifungal activity of Moringa oleifera. Int J Pharm PharmSci 6(5): 144-7

Pavithra, P. S., N. Sreevidyaand Verma, R.S. 2009. Antibacterial and antioxidant activity of methanol extract of Evolvulusnum mularius. Indian Journal of Pharmacology.41: 233-236.

Sabri, F.Z., M. Belarbi, S. Sabri and Alsayadi, M.M.S. 2012. Phytochemical screening and identification of some compounds from Mallow. J. Nat. Plant Resour., 2 (4): 512-516.

Sathishkumar, T. and Baskar, R. 2014. Screening and quantification of phytochemicals in the leaves and flowers of Tabernaemontana heyneana Wall. a near threatened medicinal plant. Ind. $J$ of Nat. Prod. and Res. Vol. 5 (3), pp. 237243.

Sathya, V., R. Bharathidasan, S. TamilSelvi, N. Sophia Rebeccal, R. Ilakkiya and
Prabakaran M. 2013. Quantitative, qualitative phytochemical analysis and in vitro antibacterial activity of Bauhinia tomentosa L. J. Nat. Prod. Plant Resour, 3(2):31-36.

Saxena, M., Saxena, J., Nema, R., Singh, D and Gupta, A. 2013. Phytochemistry of medicinal plants J. Pharm. Phytochem., 1(6): $168-82$.

Sayeed, A. M., S. M. Hossain, M. E. H. Chowdhury and Haque, M. 2012. In vitro Antimicrobial Activity of Methanolic Extract of Moringa oleifera Lam. Fruits. Journal of Pharmacognosy and Phytochemistry, 1(4), pp. 94.

Siddhuraju P., and Becker K. 2003. Antioxidant properties of various solvent extracts of total phenolic constituents from three different agroclimatic origins of drumstick tree (Moringa oleifera (Lam) leaves. J. Agric Food Chem. 51(8) pp. 2144-2155.

Solihah, M. A., W.I. Rosli and Nurhanan, A.R. 2012. Phytochemical screening and total phenolic content of Malaysian Zea mays. Int. food Res. J.., 19 (4): 1533-1538.

Ugochuhwu, S.C., A. Uche and Ifeanyi, O. 2013. Preliminary phytochemical screening of different solvent extracts of stem, bark, and roots of Dennetiatripetala. Asia J of Plant Sci and Res., 3 (3):10-13.

Vetter, R.E., and Barbosa, A. P. R. 1995. Mangrove bark: a renewable resin source for wood adhesives. Acta Amazonica., 25 (1/2): 69-72.

\section{How to cite this article:}

Elzein M. Fahal, A.M. Babitha Rani, M.D. Aklakur, T.I. Chanu and Neelam Saharan. 2018. Qualitative and Quantitative Phytochemical Analysis of Moringa oleifera (Lam) Pods. Int.J.Curr.Microbiol.App.Sci. 7(05): 657-665. doi: https://doi.org/10.20546/ijcmas.2018.705.080 